\title{
Pesan Ramah dalam Meme Akun Instagram Jaringan Gusdurian dan Fihril (Kajian Pragmatik)
}

\author{
Rifa'atul Mahmudah \\ Universitas Islam Negeri Sunan Kalijaga Yogyakarta \\ rifa.mahmudah93@gmail.com \\ Imron Gozali \\ Universitas Islam Negeri Sunan Kalijaga Yogyakarta \\ imronghozali619@gmail.com
}

\begin{abstract}
Abstrak: Meme akhir-akhir ini banyak digunakan di media sosial. Selain memiliki fungsi hiburan, meme adalah sarana transmisi pesan yang menyenangkan. Karenanya, meme banyak digemari oleh pengguna media sosial. Namun, pesan yang terdapat di dalam meme tidak terbuka (eksplisit), sehingga dalam penelitian ini digunakan teori implikatur, yang bertujuan untuk mengetahui pesan-pesan implisit dalam meme tersebut. Meme yang digunakan dari akun instagram @jaringangusdurian dan @fihril dan diambil lima meme untuk dianalisis. Metode penelitian yang digunakan adalah metode simak catat. Peneliti pertama-tama menyimak penggunaan bahasa yang mengandung fenomena implikatur. Metode analisis data yang digunakan adalah metode deskriptif-analitik. Data yang sudah peneliti catat kemudian peneliti deskripsikan sesuai dengan pengungkapan pelanggaran maksim kerjasama, pendeskripsian implikatur, dan pengungkapan jenis-jenis tindak tutur. Dari analisis terhadap meme, maka dapat ditarik kesimpulan bahwa; 1) tolongmenolong adalah perihal kemanusiaan (sosial) tanpa memandang atribut agama, suku, dan golongan; 2) sebagai sesama manusia tidak pantaslah menghakimi baik dan buruk terhadap sesamanya berdasarkan parameter keimanan saja karena tugas manusia hanyalah saling menghargai dan menghormati; 3) lebih terbuka dan kontekstual dalam memahami nilai-nilai Islam yang ramah untuk kehidupan yang bermartabat; 4) perihal nasihat-menasehati sesama manusia adalah dengan cara baik. Meskipun nasihat itu adalah benar, tetapi tetap tidak dibenarkan dengan cara yang tidak ramah.
\end{abstract}

Kata kunci: ramah, meme, instagram, pragmatik.

\begin{abstract}
The recent memes are widely used in social media. Besides having an entertainment function, memes are a means of transmitting pleasant messages. Therefore, meme is much favored by social media users. However, the message contained in the meme is not directly (explicit), so in this study used implicature theory to find out the implicit messages. The memes are used from the instagram account @jaringangusdurian and @fihril, and taken five memes for analysis. The research method used is the note-taking method. The researcher first listens to the use of languages that contain phenomena of implicature. The data analysis method used is descriptive-analytic method. The data that the researcher has noted then the researcher describes in accordance with the disclosure of violations of cooperation maxims, description of implicature, and disclosure of the types of speech acts. From the analysis of memes, it can be concluded that; 1) help is about humanity (social) regardless of the attributes of religion, ethnicity and class, 2) as fellow human beings it is not appropriate to judge good and bad towards others based on their parameters of faith, because the duty
\end{abstract}


of human beings is only to appreciate and respect each other, 3) more open and contextual in understanding friendly Islamic values for a dignified life, 4) about advising fellow humans is a good way. Even though the advice is true, it is still not justified in a non-friendly way.

Keywords: friendly, meme, instagram, pragmatic.

\section{PENDAHULUAN}

Komunikasi dalam kedudukannya dalam bahasa memiliki fungsi substansial (Khoyin, 2013), manusia selain sebagai makhluk individu juga sebagai makhluk sosial yang tidak bisa terlepas dengan interaksi antar sesamanya. Keberlangsungan hidup manusia akan sangat bergantung pada bahasa, karena manusia akan saling membutuhkan untuk memenuhi berbagai kebutuhannya. Bahkan sastra tidak akan sampai kepada pembaca tanpa melalui medium bahasa. Karenanya, bahasa memainkan peran krusial untuk mewujudkan esensi makhluk sosial itu sendiri yaitu berkomunikasi dan berinteraksi.

Seperangkat komunikasi yang digunakan adalah berupa tuturan, Wijana dalam F.X. Nadar menjelaskan agar proses komunikasi dapat berjalan lancar diperlukan kerjasama antara penutur dan lawan tutur. Prinsip kerja sama ini kemudian oleh Grice dirumuskan menjadi empat, diantaranya; maksim kuantitas, maksim ini menghendaki setiap peserta pertuturan memberikan kontribusi yang secukupnya atau sebanyak yang dibutuhkan lawan bicaranya. Maksim kualitas mewajibkan setiap peserta percakapan mengatakan hal yang sebenarnya, didasarkan pada buktibukti yang memadai. Maksim relevansi mengharuskan setiap peserta percakapan memberikan kontribusi yang relevan dengan masalah pembicaraan. Maksim pelaksanaan mengharuskan setiap peserta percakapan berbicara secara langsung, tidak kabur, dan tidak berlebihlebihan (Nadar, 2009).

Seperangkat prinsip-prinsip kerja-sama Grice di atas nampaknya bertolak belakang dengan realitas yang jamak dilakukan oleh peserta tutur, terutama di kalangan peserta tutur Jawa yang memiliki budaya mengimplisitkan maksud dari tuturannya. Kunjana Rahardi mengemukakan bahwa di dalam masyarakat tutur Jawa, justru kesantunan berbahasa banyak dimarkahi oleh ketidakjelasan, ketidaklangsungan, kekaburan, dan semacamnya (Rahardi, 2005). Fenomena bahasa ketidaklangsungan ini tentu tidak mencakup seluruh budaya di Indonesia, di Jawa biasanya untuk keakraban dan sopan santun.

Ketidaklangsungan maksud atau pesan dalam suatu komunikasi dalam pragmatik disebut implikatur. Fenomena kebahasaan seperti ini, 
sekarang banyak kita jumpai telah menjamur di media-media sosial, khususnya digunakan di dalam platform media instagram yang diwujudkan dalam bentuk meme. Shifman dalam Sari dan Arifuddin menyatakan bahwa meme adalah istilah yang diperkenalkan oleh Richard Dawkins pada tahun 1976 bahwa meme untuk menjelaskan unit kecil dari budaya yang menyebar dari satu orang ke orang lainnya dengan menyalin. Kemudian, seiring perkembangan zaman, meme telah digunakan juga di internet untuk menyebarkan banyak hal seperti lelucon, rumor, vidio, dan lain sebagainya (Arifuddin, 2018).

Meme sekarang kerapkali digemari oleh kebanyakan pengguna media sosial, hal ini bisa dilihat dengan semakin banyaknya akun-akun instagram yang menggunakan meme baik akun-akun pribadi maupun akun-akun afiliasi media seperti, jaringan gusdurian, tirto, islamidotco, fihril kamal (desainer sketsa Islam), dan lain sebagainya. Meme lebih memiliki tempat di dalam masyarakat karena sifatnya yang menghibur dan disertai dengan gambar. Oleh karenanya, meme bisa disebut sebagai humor, humor merupakan suatu hiburan yang menyenangkan yang bisa dinikmati oleh semua kalangan.

Meme yang dalam hal ini dimasukkan dalam humor mempunyai kemampuan untuk kebaikan apabila dapat dibangkitkan dalam situasi masyarakat yang sedang tidak dalam keadaan baik. Selain itu, humor yang diwujudkan dalam bentuk meme dapat membebaskan diri manusia dari beban kecemasan, kebingungan, dan kesengsaraan. Dengan demikian manusia dapat mengambil tindakan untuk memperoleh kejernihan pandangan, sehingga dapat membedakan apa-apa yang baik dan sebaliknya (Munandar, 1989).

Selain sabagai sarana hiburan, meme juga memiliki fungsi sebagai medium transmisi pesan yang hendak diungkapkan melalui makna kedua, meme tidak lahir dari ruang yang kosong. Meme bisa juga menjadi proyeksi dari suatu situasi dan kondisi sosial yang berlaku di masyarakat, yang diungkapkan dengan bentuk lain yang lebih ramah dan tidak langsung. Kendati dalam teori pragmatik fenomena kebahasaan tersebut yang termanifestasi dalam sebuah tuturan biasanya selalu melanggar kaidah atau prinsip kerjasama, misalkan prinsip kerjasama menurut Grice. Namun, justru dengan ketidakpatuhan terhadap prinsip-prinsip kerjasama tersebut akan diperoleh makna yang lebih luas dari apa yang dituturkan.

Meme yang digunakan dalam penelitian ini terdapat pada dua akun istagram yakni Jaringan Gusdurian dan Fihril, akun Jaringan Gusdurian memiliki jumlah pengikut 49,4k dan Fihril memiliki jumlah pengikut 4827. Namun, meme dari akun Fihril seringkali di unggah ulang 
oleh beberapa akun besar lainnya sehingga akun ini sangat memiliki potensi untuk dibaca oleh banyak orang. Meme-meme yang diunggah sebagian besar memiliki pesan ramah meski terkadang diwujudkan dalam bentuk satire. Untuk memperoleh tujuan-tujuan tersebut yakni mengetahui makna atau pesan tersirat dari sebuah meme, maka penelitian ini menggunakan pendekatan pragmatik dengan teori implikatur.

\section{Metode Penelitian}

Metode penelitian yang digunakan pada penelitian ini adalah metode simak catat. Peneliti pertama-tama menyimak penggunaan bahasa yang mengandung fenomena implikatur dalam meme pada akun instagram Jaringan Gusdurian dan Fihril. Kemudian setelah peneliti menyimak data-data tersebut peneliti mencatat data-data sesuai dengan kebutuhan peneliti yang mengandung fenomena bahasa implikatur. Metode analisis data, peneliti menggunakan metode deskriptif-analitik. Data yang sudah peneliti catat kemudian peneliti deskripsikan sesuai dengan langkah-langkah yaitu pengungkapan pelanggaran maksim kerjasama, pendeskribsian implikatur, dan pengungkapan jenis-jenis tindak tutur.

\section{Landasan Teori}

Konsep implikatur pertama kali dikenalkan oleh H.P. Grice (1975) untuk memecahkan persoalan makna bahasa yang tidak dapat diselesaikan oleh teori semantik biasa (Idris, 2013). Menurut Mey, implikatur "implicature" berasal dari kata kerja to imply sedangkan kata bendanya adalah implication. Kata kerja ini berasal dari bahasa latin plicare yang berarti to fold "melipat", sehingga untuk mengerti apa yang dilipat atau apa yang disimpan tersebut haruslah dilakukan dengan cara membukanya (Nadar, 2009).

Definisi menurut Yule, implikatur adalah contoh utama dari banyaknya informasi yang disampaikan dari pada yang dikatakan. Supaya implikatur-implikatur tersebut dapat ditafsirkan maka beberapa prinsip kerjasama dasar harus lebih dini diasumsikan dalam pelaksanaannya (Yule, 2006). Laurence R. Horn dan Gregory Ward mendefinisikan implikatur sebagai: "Implicature is a component of speaker meaning that constitutes an aspect of what is meant in a speaker's utterance without being part of what is said" (Implikatur adalah komponen makna penutur yang mengacu pada aspek makna yang dimaksud olehnya dengan tanpa memasukkan makna ke dalam apa yang ia katakan) (Ward, 2006). 
Grice dalam Mas'ud Shahrawi menyatakan bahwa kalimat -dalam beberapa kondisi (konteks)- menandakan pada makna yang tidak terkandung secara langsung di dalam kalimat tersebut (Shahrawi, 2005). Hal yang senada diungkapkan oleh Kartomiharjo bahwa implikatur adalah tuturan yang menyiratkan sesuatu yang berbeda dengan yang sebenarnya diucapkan (Shahrawi, 2005).

Berdasarkan beberapa pengertian di atas maka dapat disimpulkan bahwa implikatur adalah makna penutur yang tidak terdapat dalam tuturan, maknanya tidak bisa tertangkap secara harfiah dari sebuah tuturan melainkan ada di luar tuturan.

Di dalam implikatur, hubungan antara tuturan yang bersifat sesungguhnya dengan maksud yang tidak dituturkan itu bersifat tidak mutlak (Rahardi, 2005). Dengan kata lain, inferensi (simpulan) sifatnya tidak terbatas, namun untuk membatasi ketepatan maksud dari sebuah tuturan diperlukan adanya konteks. Hal ini senada dengan yang telah diungkapkan oleh Djatmika bahwa ketidaklangsungan yang dilakukan oleh penutur menjadikan mitra tutur atau bahkan orang lain yang tidak terlibat langsung dituntut untuk peka terhadap apa yang dimaksud oleh penutur, oleh karenanya kedua belah pihak diharapkan memiliki background knowledge yang sama (Djatmika, 2016).

Implikatur dapat diidentifikasi denga ciri-ciri: (1) Implikatur tidak dinyatakan secara eksplisit, (2) Tidak memiliki hubungan mutlak dengan tuturan yang merealisasikannya (apa yang diucapkan dengan apa yang dimaksudkan), (3) Termasuk unsur luar wacana, (4) Implikatur dapat dibatalkan, (5) Bersifat terbuka penafsiran atau banyak makna (multi interpretable), dan (6) Terjadi karena mematuhi atau tidak mematuhi prinsip kerjasama dalam percakapan (Fauzi, Pragmatik dan Ilmu Ma'aniy: Persinggungan Ontologik dan Epistemologik , 2012).

Secara garis besar, terdapat dua jenis implikatur menurut Grice, yaitu yang bersifat conventional (konvensional) dan yang bersifat conversational (percakapan). Pertama, implikatur konvensional, pada jenis ini makna suatu ujaran sudah menjadi konvesional atau secara umum diterima oleh masyarakat (Idris, Stilistika Al-Quran: Kajian Pragmatik , 2013). Implikatur konvensional tidak didasarkan pada prinsip kerja sama atau maksim-maksim. Implikatur konvensional tidak harus terjadi dalam percakapan, dan berbeda dengan implikatur percakapan yang mengharuskan berada dalam sebuah percakapan, maka implikatur konvensional tidak demikian. Selain itu, maknanya sudah bisa ditangkap melalui kata-kata yang diujarkan tidak bergantung pada konteks khusus untuk menginterpretasikannya (Yule, 2006). 
Kedua, Grice menyebut implikatur nonkonvensional sebagai implikatur percakapan (Grice, 2004), implikatur percakapan adalah ujaran yang menyiratkan sesuatu yang berbeda dengan sebenarnya (Idris, Stilistika Al-Quran: Kajian Pragmatik , 2013). Levinson dalam Andyka, implikatur percakapan muncul dalam suatu tindak percakapan, oleh karena itu sifatnya temporer (terjadi saat berlangsungnya tindak percakapan), dan non konvensional (sesuatu yang diimplikasikan tidak mempunyai relasi langsung dengan tuturan yang diucapkan) (Farid, 2012).

Menurut Grice, implikatur percakapan muncul akibat pelanggaran salah satu dari empat maksim, yaitu maksim kuantitas, maksim kualitas, maksim relevansi, dan maksim pelaksanaan/cara. Implikatur konvensional muncul dari makna kata yang disepakati secara konvensional sedangkan implikatur percakapan muncul karena adanya pelanggaran maksim. Implikatur pada prinsipnya merupakan maksud tuturan. Maksud tuturan yang menyatakan suatu tindakan, seperti meminta, menyarankan, dan sebagainya (Kasei, 2017).

Grice di atas telah mendasarkan bahwa implikatur percakapan muncul karena adanya pelanggaran terhadap prinsip kerjasamanya. Menurut Grice pula, wacana yang mendasarkan terhadap kepatuhan terhadap prinsip kerjasama komunikasi (cooperative principles) adalah wacana yang wajar. Adapun maksim-maksim yang harus dipatuhi, yaitu; maksim kuantitas, maksim ini menghendaki peserta percakapan memberikan kontribusi yang secukupnya atau sebanyak yang dibutuhkan oleh lawan bicara (Wijana, 2004).

Maksim kualitas tidak mensyaratkan peserta tutur bertutur secukupnya, melainkan untuk mengatakan hal yang sebenarnya, didasarkan pada bukti-bukti yang memadai. Maksim relevansi, maksim ini menghendaki peserta tutur memberikan kontribusi yang relevan dengan masalah pembicaraan. Sedangkan maksim pelaksanaan mengharuskan peserta tutur berbicara secara langsung, tidak berbelitbelit, tidak kabur, tidak taksa, tidak berlebih-lebihan, serta runtut (Wijana, 2004).

\section{Tindak Tutur}

Leech dalam Idris menyatakan bahwa Searle mengklasifikasi tindak tutur (klasifikasi tindak ilokusi) menjadi lima, yaitu: representatif/asertif/konstantif, direktif, ekspresif, komisif, deklaratif (Idris, Stilistika Al-Quran: Kajian Pragmatik , 2013). Pengertian masingmasing tindak tutur sebagai berikut: 
Rifa'atul Mahmudah \& Imron Gazali: Pesan Ramah dalam Meme Akun Instagram Jaringan

Gusdurian dan Fihril

| 123

(1) Tindak tutur representatif adalah tindak tutur yang mengikat penuturnya pada kebenaran atas hal yang dikatakannya, (2) direktif adalah tindak tutur yang dilakukan oleh penutur dengan maksud agar lawan tutur melakukan tindakan yang disebutkan dalam ujaran, (3) ekspresif adalah tindak tutur yang dilakukan dengan maksud agar ujarannya diartikan sebagai evaluasi tentang hal yang disebut di dalam ujarannya itu, (4) komisif adalah tindak tutur yang mengikat penuturnya untk melaksanakan segala hal yang disebutkan dalam ujarannya, (5) deklaratif adalah tindak tutur yang dilakukan penutur dengan maksud untuk menciptakan hal yang baru (Idris, Stilistika Al-Quran: Kajian Pragmatik, 2013).

\section{HASIL DAN PEMBAHASAN}

Analisis data di bawah ini akan ditampilkan berdasarkan pelanggaran maksim kerjasama, kemudian dimunculkan makna yang tersirat (implikatur), dan dipaparkan jenis tindak tutur yang digunakan.

\section{Data 1}

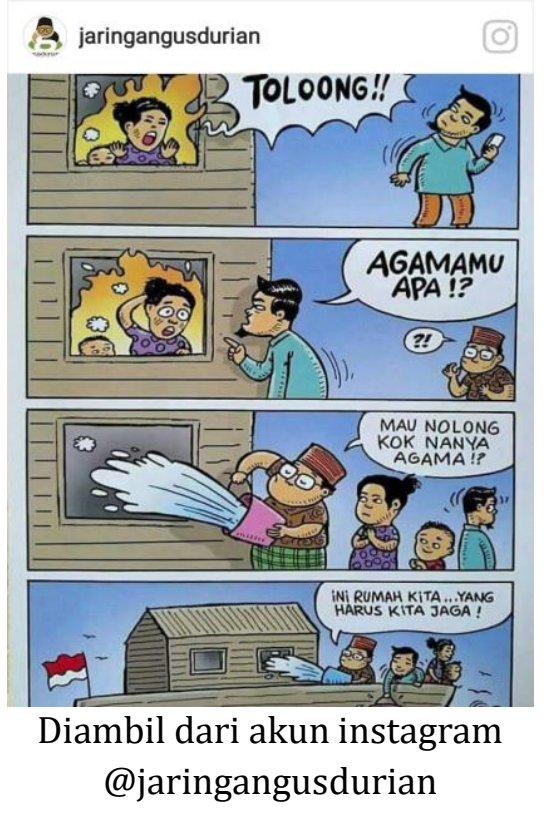

\section{Tuturan:}

P1: Tolong!!!

P2: Agamamu apa!?

P3: Mau nolong kok nanya

Agama!?

P3: Ini rumah kita yang harus

kita jaga.

Penjelasan peristiwa: 
P1: Seorang ibu dan anaknya berkata: Tolong!!! Tuturan ini diutarakan bertepatan dengan suatu ruangan yang terbakar dan mereka berdua berada di dalam ruangan tersebut. Tuturan "tolong" dituturkan dengan tidak diberikan alasan mengapa ibu terbut berteriak tolong.

P2: Kemudian seorang pemuda manghapiri mereka berdua, dalam keadaan ruangan yang mereka tempati terbakar, lalu bertanya: Agamamu apa!?

P3: Kemudian gus dur datang, dengan membawa ember yang berisi air, lalu menyiram kobaran api dan bertanya, Mau nolong kok nanya Agama!? Kemudian gus dur berkata lagi: Ini rumah kita yang harus kita jaga.

\section{Pelanggaran Maksim}

Apabila diperhatikan percakapan di atas p1 memberikan informasi berupa kata "tolong!!!" tanpa disertai dengan penjelasan mengapa ia meminta tolong. Dalam kajian pragmatik tuturan ini melanggar maksim kuantitas karena penutur hanya memberikan informasi yang tidak lengkap berupa tuturan "tolong!!!”. Selain melanggar maksim kuantitas, p1 juga melanggar maksim pelaksanaan karena menimbulkan ketaksaan.

Sedangkan p2 yang menjadi lawan tutur dari p1 menuturkan "Agamamu apa!?" Pada konteks ini p2 bukan menanyakan mengapa p1 meminta tolong namun p2 justru menayakan "Agamamu apa!?" Apa yang dituturkan oleh p2 dalam kajian pragmatik melanggar maksim kualitas dari tuturan $\mathrm{p} 1$ karena seharusnya $\mathrm{p} 2$ memahami apa yang telah terjadi dengan langsung membawa air bukan justru menanyakan "Agamamu apa!?" Sebab, konteks saat itu terjadi kebakaran di dalam ruangan tersebut. Kemudian p3 yang merupakan sosok yang digambarkan serupa dengan Gus Dur datang dengan membawa ember yang berisi air lalu menyiram kobaran api yang berada di dalam ruangan dan berkata "mau nolong kok nanya agama?" Dalam kajian pragmatik p3 melanggar maksim relevan karena p3 menuturkan "mau nolong kok nanya agama?" disertai dengan tindakan menyiramkan air ke arah api yang mengakibatkan api padam.

\section{Implikatur}

Pada konteks ini implikaturnya adalah terletak pada tuturan p3 yaitu "mau nolong kok nanya agama?" Karena p3 dalam konteks ini memiliki maksud di dalam tuturannya yaitu perihal menolong sesama manusia kita tidak perlu menanyakan agama, ras, dan suku. Dalam konteks ini yang harus dijaga adalalah rasa kemanusiaan dan kebersamaan agar hidup guyup, rukun dan setara. 
Rifa'atul Mahmudah \& Imron Gazali: Pesan Ramah dalam Meme Akun Instagram Jaringan Gusdurian dan Fihril

Jenis Tindak Tutur dalam Pengungkapan Implikatur

Dari teks di atas apabila dilihat dari sudut pandang tindak tutur maka tuturan p3 termasuk dalam tindak tutur direktif. Tindak tutur direktif dari tuturan p3 dapat ditemukan dalam tuturan "mau nolong kok nanya agama?" disertai tindakan p3 yaitu menyiram air ke arah api. Tuturan "mau nolong kok nanya agama?" disertai tindakan menyiram api memiliki dampak terhadap p2 baik secara fisik dan psikis. Adapun secara psikis yaitu p2 memiliki rasa malu dan sadar diri karna dalam tolongmenolong ia masih memandang batasan agama. Sedangkan dampak secara fisik ia lebih tanggap dalam tindakan saat keadaan buruk sedang terjadi seperti mengutamakan keselamatan orang lain, karena justru itulah ajaran agama sesungguhnya.

\section{Data 2}

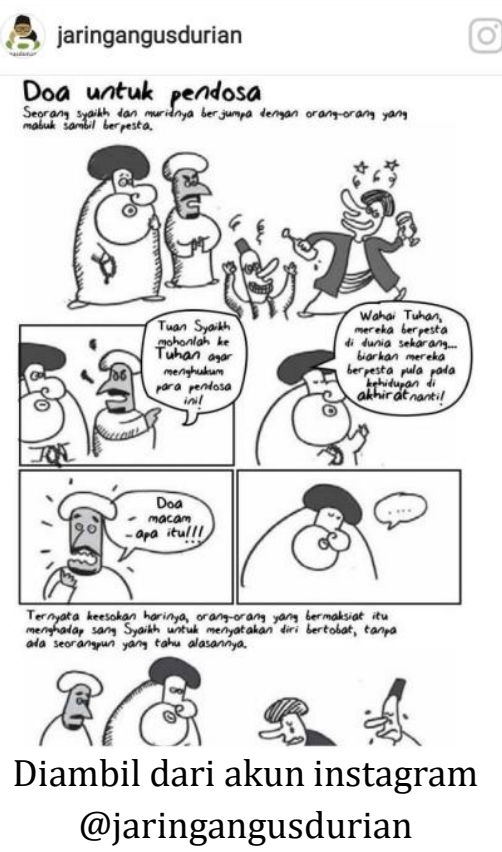

\section{Tuturan:}

\section{Doa untuk pendosa}

(Seorang syeikh dan muridnya berjumpa dengan orang-orang yang mabuk sambil berpesta)
P1 (Murid): Tuan Syaikh mohonlah ke Tuhan agar manghukum para pendosa ini!
P2 (Syekh): Wahai Tuhan, mereka berpesta di dunia sekarang, biarkan mereka berpesta pula pada kehidupan di akhirat nanti!

P1: Do'a macam apa itu!!!

P2: ....

\section{Pelanggaran Maksim}

Dari percakapan di atas, sang murid memohon do'a kepada sang syeikh agar para pemabuk yang berpesta dihukum Tuhan sesuai dengan perbuatannya. Kemudian sang syekh berdo'a "Wahai Tuhan mereka berpesta di dunia sekarang, biarkan mereka berpesta pula pada kehidupan di akhirat nanti!" Dalam prespektif pragmatic, do'a yang dibacakan oleh 
syeikh kepada para pemabuk melanggar maksim kualitas karna tidak sesuai dengan permohonan muridnya. Sang murid memohon agar mereka dihukum oleh Tuhan sedangkan sang syeikh bukan berodo'a demikian melainkan agar mereka dapat berpesta di dunia dan diakhirat.

\section{Implikatur}

Dari percakapan di atas implikaturnya terdapat pada do'a sang syekh. Adapun maksud dari dari tuturan do'a tersebut adalah bahwa dalam memandang orang yang bermaksiat, untuk mendo'akan keburukan saja tidak diperkenankan. Dari do'a tersebut tersirat makna pula bahwa jangan selalu memandang buruk seseorang yang sedang bermaksiat bisa jadi pandangan saat ini mereka begitu namun belum tentu di kemudian hari.

\section{Jenis Tindak Tutur dalam Pengungkapan Implikatur}

Apabila dilihat dari prespektif tindak tutur tuturan, yang berupa do'a syeikh kepada Tuhan untuk para pemabuk, maka termasuk dalam tindak tutur konstatif. Hal ini dikarenakan tuturan sang syeikh kepada murid bukan hanya sekedar tuturan biasa semata melainkan memiliki tujuan tertentu. Adapun tujuan dari tuturan syeikh adalah sebagai nasehat kepada muridnya agar tak memandang orang yang bermaksiat selalu salah. Sedangkan dari tuturan sang syeikh memiliki dampak baik secara psikis dan fisik. Secara psikis ia harus banyak berpikir sebelum berkata dan secara fisik ia tidak lagi mengulangi perbuatannya yang berupa memohon suatu perkara yang buruk untuk orang lain.

\section{Data 3}




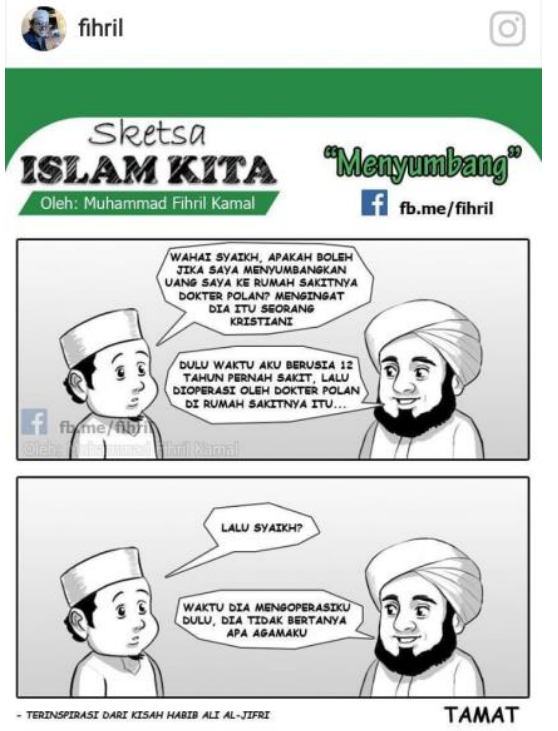

Diambil dari akun instagram @fihril

\section{Tuturan:}

P1 (Murid): Wahai Syekh, apakah boleh jika saya menyumbangkan uang saya ke rumah sakitnya Dokter Polan? Mengingat dia itu seorang kristiani.

P2 (Syeikh): Dulu waktu aku berusia 12 tahun pernah sakit, lalu dioperasi oleh dokter polan di rumah sakitnya itu.

P1: Lalu syeikh?

P2: Waktu dia mengoperasiku dulu, dia tidak bertanya apa agamaku.

\section{Pelanggaran Maksim}

Dari percakapan di atas, apabila dilihat dari prespektif pragmatik, maka syeikh melanggar maksim relevansi dari tuturan sang murid. Yang dilanggar dari sang syekh adalah tuturan yang berupa pertanyaan "wahai Syekh, apakah boleh jika saya menyumbangkan uang saya ke rumah sakitnya Dokter Polan? Mengingat dia itu seorang kristiani. Seharusnya, sang syeikh menjawab pertanyaan sang murid, dengan jawaban iya atau tidak, bukan menceritakan dirinya di waktu berumur 12 tahun.

\section{Implikatur}

Pada konteks ini, implikaturnya terletak pada jawaban sang syeikh yang menceritakan ia saat berumur 12 tahun. Syeikh dioperasi oleh Dokter Polan dan dokter tidak menanyakan apa agama sang syeikh. Adapun maksud tuturan syeikh yang berupa jawaban tersebut adalah dalam hal tolong-menolong sang murid tidak harus memandang perbedaan baik dalam agama, suku, ras dan lain-lain. Namun yang dipandang adalah rasa kemanusiaan yang harus lebih didahulukan dan dipentingkan.

\section{Jenis Tindak Tutur dalam Pengungkapan Implikatur}

Dari implikatur di atas dalam prespektif tindak tutur maka termasuk dalam tindak tutur konstatif karena syekh hanya mengatakan 
suatu informasi kepada muridnya. Namun tuturan konstatif tersebut memiliki dampak baik dari segi psikis dan fisik. Adapun secara psikis murid dari syekh tersebut menyadari bahwa jika melakukan kebaikan berupa menyumbangkan uang tidak perlu memandang siapa yang akan menerima. Sedangkan secara fisik murid langsung memberikan uang untuk dokter polan dan tidak pikir-pikir lagi dalam menyumbangkan uangnya.

\section{Data 4}




\section{Tuturan:}

\section{Pakaian Taqwa}

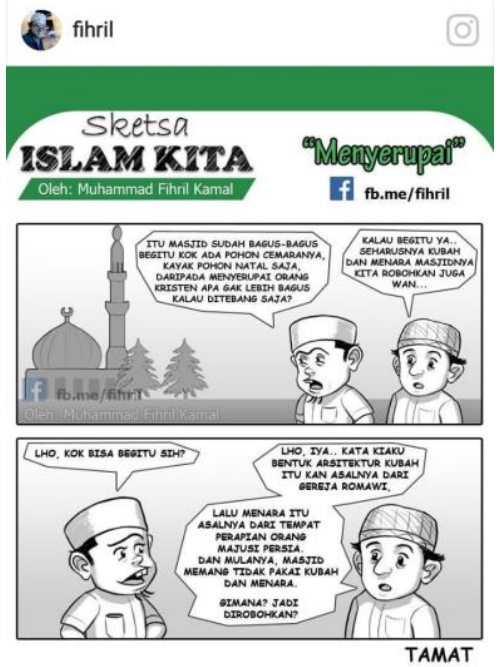

Diambil dari akun instagram @fihril
P1: Itu masjid sudah bagus-bagus begitu kok ada pohon cemaranya, kayak pohon natal saja, daripada menyerupai orang kristen apa gak lebih bagus kalau ditebang saja?

P2: Kalau begitu ya.. seharusnya kubah dan menara masjidnya kita robohkan juga wan...

P1: Lho, kok bisa begitu sih?

P2: Lho, iya.. Kata kiaku bentuk arsitektur kubah itu kan asalnya dari gereja romawi,

Lalu menara itu asalnya dari tempat perapian orang majusi persia. Dan mulanya, masjid memang tidak pakai kubah dan menara. Gimana? Jadi dirobohkan?

\section{Pelanggaran Maksim}

P2 dalam percakapan di atas telah melanggar maksim relevansi, seharusnya p2 menjawab dari pertanyaan yang diajukan oleh p1, akan tetapi p2 memberi balasan dengan sebuah pernyataan yang justru menimbulkan pertanyaan dari p1 dalam tuturan selanjutnya "lho, kok bisa begitu sih?". Selain melanggar maksim relevansi, p2 juga melanggar maksim kualitas karena p2 mengutarakan pernyataan yang tidak sesuai dengan pertanyaan yang diuatarakan oleh $\mathrm{p} 1$ dalam tuturan pertamanya. Implikatur

Pelanggaran maksim yang dilakukan oleh p2 berimplikasi terhadap maksud yang lebih luas yang tidak terdapat di dalam pernyataannya, "kalau begitu ya.. seharusnya kubah dan menara masjidnya kita robohkan juga wan...", dan hal ini yang dinamakan implikatur. Jadi, implikatur dalam tuturan tersebut adalah laki-laki tersebut ingin menunjukkan bahwa sebagai orang Islam hendaknya dalam melihat segala sesuatu yang tidak berhubungan dengan Islam jangan hanya secara kasat mata saja, justru harus melihat dengan 
kacamata Islam yang ramah. Padahal, jika ditelisik lebih lanjut bahwa masjid sebagai tempat ibadah orang Islam khususnya di Indonesia juga telah mengalami akulturasi baik dengan budaya lokal maupun internasional. Bahkan cara dakwah para walisongo juga tidak serta merta membuang budaya lokal yang sama sekali tidak memiliki nilai-nilai Islam itu, melainkan dengan ramah dan santun memasukkan nilai-nilai Islam ke dalam budaya lokal.

Sehingga kira-kira laki-laki tersebut ingin mengungkapkan konsep pribumisasi Islam Gus Dur bahwa Gus Dur melalui konsep ini ingin melakukan upaya rekonsiliasi Islam dengan kekuatan-kekuatan budaya setepat, agar budaya lokal tidak hilang. Menurut Gus Dur pula formalisasi seperti ini adalah akibat dari ketidakpercayaan diri terhadap kemajuan Barat, sehingga solusinya adalah dengan menyubordinasikan diri ke dalam konstruk Arabisasi. Padahal Arabisasi berbeda dan bukan Islamisasi, yang arab belum tentu Islami (Wahid, 2006).

\section{Jenis Tindak Tutur dalam Pengungkapan Implikatur}

Dari implikatur di atas dalam prespektif tindak tutur maka tuturan di atas termasuk dalam tindak tutur konstatif. Karena p2 hanya memberikan tuturan "berupa jawaban kalau begitu ya.. seharusnya kubah dan menara masjidnya kita robohkan juga wan...". Namun, tuturan tersebut memiliki daya pengaruh baik secara psikis dan fisik. Adapun secara psikis $\mathrm{p} 1$ harus lebih berpikir sebelum mengatakan sesuatu kepada p2. Sedangkan dampak fisiknya ia tidak lagi mengulangi perbuatnya yaitu bertutur dengan hanya melihat kulitnya saja.

\section{Data 5}




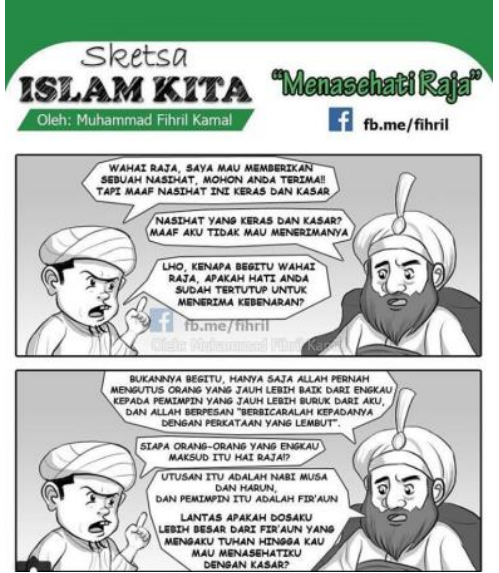

Diambil dari akun instagram @fihril
Tuturan:

P1: Wahai raja, saya mau memberikan sebuah nasihat, mohon anda terima!! Tapi maaf nasihat ini keras dan kasar

P2: Nasihat yang keras dan kasar? Maaf aku tidak mau menerimanya

P1: Lho, kenapa begitu wahai raja, apakah hati anda sudah tertutup untuk menerima kebenaran?

P2: Bukannya begitu, hanya saja Allah pernah mengutus orang orang yang jauh lebih baik dari engkau kepada pemimpin yang jauh lebih buruk dari aku, dan Allah berpesan "Berbicaralah kepadanya dengan perkataan yang lembut"

P1: Siapa orang-orang yang engkau maksud itu hai raja?

P2: Utusan itu adalah Nabi Musa dan Harun, dan pemimpin itu adalah Fir'aun.

Lantas apakah dosaku lebih besar dari Fir'aun yang mengaku Tuhan hingga kau mau menasehatiku dengan kasar?

\section{Pelanggaran Maksim}

Dari percakapan di atas dapat ditemui pelanggaran maksim yaitu pada tuturan raja "utusan itu adalah nabi Musa dan Harun, dan pemimin itu adalah firaun. Lantas aoakah dosaku lebih besar dari fir'aun yang mengaku tuhan hingga kau mau menasehatiku dengan kasar?" Tuturan tersebut seharusnya cukup berupa jawaban saja karena pemuda tersebut hanya menanyakan siapa orang-orang yang raja maksud. Namun raja justru memberikan pertanyaan kepada pemuda tersebut. Oleh karena raja pada konteks ini melanggar maksim kuantitas, karna ia tidak hanya sekedar menjawab namun menambahi pertanyaan. Meskipun secara konten berisi tuturan yang baik, namun dalam pragmatik hal ini melanggar maksim. 


\section{Implikatur}

Dari teks di atas maka implikturnya terdapat pada tuturan sang raja "Utusan itu adalah nabi Musa dan Harun, dan pemimin itu adalah firaun. Lantas apakah dosaku lebih besar dari fir'aun yang mengaku tuhan hingga kau mau menasehatiku dengan kasar?" Tuturan ini dimaksudkan agar sang pemuda memiliki sopan santun saat memberikan nasehat dan tidak dengan cara yang ia anggap benar. Meskipun menasehati itu adalah benar, namun tetap tidak dibenarkan dengan cara yang tidak lembut. Hal ini bisa dilihat dari tuturan sang raja yang mencontohkan orang yang jauh lebih baik daripada lawan tutur sang raja adalah Nabi Musa dan Nabi Harun dan pemimpin yang lebih buruk dari sang raja adalah Fir'aun. Kedua Nabi tersebut diperintah untuk memberi nasihat dengan lembut.

\section{Jenis Tindak Tutur dalam Pengungkapan Implikatur}

Apabila dilihat dari prespertif tindak tutur maka pertanyaan raja pada konteks ini termasuk dalam tindak tutur direktif. Hal ini dikarenakan selain raja menuturkan sesuatu ia juga menuntut kepada lawan tutur untuk melakukan sesuatu. Pertanyaan yang disampai oleh sang raja kepada pemuda tersebut memiliki dua dampak yaitu psikis dan fisik. Dampak psikisnya adalah pemuda tersebut akan berfikir lebih matang dalam mengucapkan sesuatu, baik itu perkataan maupun nasehat. Sedangkan dampak fisiknya ia tidak mengulangi apa yang ia lakukan kepada sang raja.

\section{Penutup}

Jenis implikatur yang digunakan dalam penelitian ini adalah implikatur percakapan (nonkonvensional). Untuk bisa menemukan maksud tersirat (implikatur) maka harus dipaparkan terlebih dahulu pelanggaran-pelanggaran maksim kerjasama, karena jika tidak terdapat perlanggaran maksim maka tidak akan dijumpai implikatur. Sebagaimana dalam penelitian ini, pelanggaran yang dilakukan diantaranya adalah maksim kuantitas, kualitas, relevansi/hubungan, dan pelaksanaan. Namun, pelanggaran terhadap maksim-maksim tersebut menyebar di seluruh data. Sedangkan jenis tindak tutur yang digunakan diantaranya; direktif dan konstatif.

Pembahasan mengenai makna tersirat terhadap lima meme di atas memberikan pesan utama bahwa meme-meme yang ada di akun instagram @jaringangusdurian dan @fihril, tidak hanya memiliki nilai hiburan semata, melainkan untuk menyebarkan pesan-pesan ramah dan toleran. Sebagaimana terdapat pada data 1, bahwa tolong-menolong 
Rifa'atul Mahmudah \& Imron Gazali: Pesan Ramah dalam Meme Akun Instagram Jaringan \begin{tabular}{l|l} 
Gusdurian dan Fihril $\quad 133$
\end{tabular}

adalah perihal kemanusiaan (sosial) tanpa memandang atribut agama, suku, dan golongan. Data 2 menyampaikan pesan bahwa sebagai sesama manusia tidak pantaslah menghakimi baik dan buruk terhadap sesamanya berdasarkan parameter keimanan saja, karena tugas manusia hanyalah saling menghargai dan menghormati.

Sedangkan data 3, pesan yang ingin disampaikan juga masih berhubungan dengan sosial, bahwa urusan sosial memang harus selalu dikedepankan, menolong orang (berobat) lebih utama tanpa bertanya atribut agamanya apa. Pada data 4, pesan yang disampaikan adalah untuk lebih terbuka, bahwa semua hal yang berhubungan dengan Arab belum tentu Islam, sehingga dengan begitu tidak mudah mengklaim orang Islam lain sebagai kurang kaffah dan lain sebagainya, dan yang terpenting adalah mengkontekstualisasikan nilai-nilai Islam yang ramahlah untuk kehidupan yang bermartabat. Data 5 menyampaikan bahwa dalam hal nasihat-menasehati sesama manusia adalah dengan cara ramah. Meskipun nasihat itu adalah benar. Namun, tetap tidak dibenarkan dengan cara yang tidak lembut.

\section{Daftar Rujukan}

Arifuddin, A. A. (n.d.). Bentuk dan Makna Meme Berbahasa Arab dalam Media Sosial Instagram Shuwarun Mundhchikatun. CMES, 16.

Djatmika. (2016). Mengenal Pragmatik Yuk! Yogyakarta: Pustaka Pelajar.

Farid, A. M. (2012). Implikatur-implikatur Percakapan dalam Wacana Humor Gus Dur (Skripsi). Surakarta: Universitas Sebelas Maret .

Fauzi, M. S. (2012). Pragmatik dan Ilmu Ma'aniy: Persinggungan Ontologik dan Epistemologik. Malang: UIN-Maliki Press.

Fauzi, M. S. (2012). Pragmatik dan Ilmu Ma'aniy: Persinggungan Ontologik dan Epistemologik. Malang: UIN- Maliki Press.

Grice, H. P. (2004). Logic and Conversation . London: University College London.

Idris, M. (2013). Stilistika Al-Quran: Kajian Pragmatik. Yogyakarta: Karya Media.

Idris, M. (2013). Stilistika Al-Quran: Kajian Pragmatik. Yogyakarta: Karya Media.

Kasei, I. N. (2017). Implikatur yang Terungkap dalam Buku Humor Nyentrik Ala Gus Dur. Jurnal Bahasa, dan Pembelajarannya (JBSP), 126. 
Khoyin, M. (2013). Filsafat Bahasa. Bandung: Pustaka Setia.

Munandar, S. U. (1989). Humor (dalam Ensiklopedi Nasional Indonesia, Jilid VI). Jakarta: PT. Cipta Adi Pustaka.

Nadar, F. (2009). Pragmatik dan Penelitian Pragmatik. Yogyakarta: Graha Ilmu.

Rahardi, R. K. (2005). Pragmatik: Kesantunan Imperatif Bahasa. Jakarta: Erlangga.

Shahrawi, M. (2005). al-Tadawuliyah 'Inda al-'Ulama al-'Arab: Dirasah tadawuliyah lidhahirah al-Af'al al-Kalamiyah fi al-Turats al-Lisani al'Arabi . Beirut: Dar al-Thali'ah.

Wahid, A. (2006). Islamku, Islam Anda, Islam Kita: Agama Masyarakat Negara Demokrasi. Jakarta: The Wahid Isntitute.

Ward, L. R. (2006). The Handbook of Pragmatics. United Kingdom: Blackwell Publishing.

Wijana, I. D. (2004). Kartun. Yogyakarta: Ombak.

Yule, G. (2006). Pragmatik, Terjemahan: Indah Fajar Wahyuni. Yogyakarta: Pustaka Pelajar. 